\title{
Integration and Productivity of Labor Factor in Europe. Perspective from Nationality and the Attainment Level
}

\author{
Antonio Mihi-Ramirez ${ }^{1}$, Elias Melchor-Ferrer ${ }^{2}$, Janusz Sobieraj $^{3}$ \\ 1, 2 University of Granada \\ Campus Cartuja, 18071, Granada, Spain \\ E-mail.amihi@ugr.es ${ }^{1}$;emelchor@ugr.es ${ }^{2}$ \\ ${ }^{3}$ Warsaw University of Technology \\ Al. Armii Ludowej 16, Warsaw, Poland \\ E-mail.jsob@il.pw.edu.pl ${ }^{3}$ \\ cross $^{\text {ref }}$ http://dx.doi.org/10.5755/j01.ee.31.1.24477
}

\begin{abstract}
Productivity in Europe remains stagnant over a long period of time for several reasons: structural barriers hampering proper development and the diffusion of innovations; and also due to high structural unemployment. This puts a significant brake on growth and competitiveness. A high-potential alternative for improving productivity lies in increasing labour participation and the attraction/retention of talent as a result of European integration. Therefore, this study examines how economic growth is affected by labour productivity and the local and foreign workers' employment rates, as well as their level of achievement. Using the Durbin Spatial Model (DSM), we analyse OECD data from 13 European countries covering the period 2000-2017. Our results confirm, first of all, that there has been a positive convergence among European countries and that it is of considerable benefit for the growth of countries with different levels of development. In terms of labour productivity, it positively influences economic growth, especially for highly skilled local workers. Moreover, it is confirmed that increased participation has a statistically significant impact on each country's growth rate in the studied sample. In terms of educational levels, an increase in the number of workers with a high and medium level of education entails a growth that is also transferred to neighbouring countries. Also, these types of strategies serve to create conditions that allow for attracting and retaining talent in the long term, which also generates positive effects on growth itself, but also for neighbouring countries in the same area of integration.
\end{abstract}

Keywords: Labour Productivity; International Migration; Convergence in the European Union; Level of Education of Workers; Employment.

\section{Introduction}

Productivity is crucial for the level of development (OECD, 2019a; Mihi-Ramirez et al., 2018), but its global growth has remained very limited. In fact, productivity growth for the Eurozone has declined from $2 \%$ in the $1990 \mathrm{~s}$ to less than $0.5 \%$ today, and this is also the case in the United States and other developed economies (OECD, 2019a; Gordon, 2016; European Commission, 2014; Ark et al., 2008). Although economic cycles can partially explain this, the main reasons are due to the persistence of structural problems (Greenstone et al., 2010; Lewis, 2005). If the economic slowdown continues, it will have a major impact on our future prosperity and also will have direct consequences for the cohesion of the European Union (Draghi, 2016).

Productivity levels depend on the quantity and quality of labour and capital (Ojeda-Gonzalez et al., 2018a; European Commission, 2014). The process of European integration has led to the mobility of large flows of capital and labour (OjedaGonzalez et al., 2018; Miranda-Martel et al., 2018; Gamberoni et al., 2016). However, the growth of these countries varies noticeably (Mihi-Ramirez et al., 2019; Melchor-Ferrer et al., 2018; OECD, 2015). From the productivity perspective, it is not clear whether this growth is driven by an accumulation of labour and capital or by innovations which improve the use of those resources. These productive factors are opportunely more receptive to structural reforms than to innovations, which are more inflexible in view of regulatory changes (Draghi, 2016). For this reason, in the development of European companies and economies it might be advisable to give greater priority for the attraction of capital and labour (workers).

As for capital, the experience of several European countries, such as Spain, shows that growth has been primarily based on the accumulation of productive assets, with productivity remaining at very low levels for long stretches of time (Gamberoni et al., 2016; Ciccone \& Hall, 1996).

And what happens to productivity during the European integration process when assessed from the labour factor standpoint? Accumulation of labour and attractions of workers require well-functioning capital markets, as well as product and labour markets (Ojeda-Gonzalez et al., 2018b; Miranda-Martel et al., 2017; Gordon, 2016). Moreover, the current low levels of productivity per worker, employment and labour force participation result in an increased ageing of the population in European countries, leading to a decline in the output per capita over the long term (Klugea et al., 2019; Conesa \& Kehoe, 2018; OECD, 2015) whilst also representing a step backwards in terms of the convergence in the European Union. 
Furthermore, the free movement of European workers (i.e. migratory flows) has proven to be an effective strategy for reducing the structural unemployment rate, rejuvenating the labour market and increasing the participation rate (MihiRamirez et al., 2019; Miranda-Martel et al., 2017; Gamberoni et al., 2016). It has also been observed that the increase in the number of immigrants plays an important role in the growth of Gross Domestic Product per capita, GDPPC ${ }^{1}$ (GarciaRodriguez et al., 2015). However, the impact of immigration on productivity varies from country to country (MirandaMartel et al., 2018; Melchor-Ferrer et al., 2017; Peri, 2016; Kangasniemi et al., 2009).

Therefore, the aim of this paper is to analyse the impact and efficiency of labour productivity in European economies, and this involves several steps: 1 ) to examine how the process of European integration has contributed to the economic growth or slowdown in different European economies; 2) to analyse whether labour has been utilised efficiently, i.e. how labour productivity has evolved in European countries; 3) to study the impact of local and immigrant labour on employment and growth; 4) to analyse labour productivity taking into account differences in the quality of local and immigrant labour in these countries (by educational level).

The research problem can be formulated through the following key questions: How the European integration contributes to the growth of the European countries? What is the impact of local and foreign workers on labour productivity and employment in Europe?

What are the effects of the quality of local and migrant workers (as measured by their educational level) on labour productivity in Europe?

This paper examines these issues for several European countries so as to learn why there are differences in growth and productivity levels between these countries. The productivity analysis between local workers and immigrants is also studied on a separate basis, thereby allowing very important comparisons to be made in an economic area with free labour mobility. It also takes into account whether the educational level of the labour force is relevant.

The methodology consists of the Durbin Spatial Model (DSM) to test data on GDPPC, local and foreign labour productivity and employment rates in 13 OECD European countries $(2019 b, 2018)$ in the period 2000-2017.

The following sections are covered in the paper: theoretical approach, methodology, discussion of the results, and the key points.

\section{Theoretical Framework}

Total production growth depends, among other factors, on an increased labour productivity (Mihi-Ramirez et al., 2019; Requeijo, 2009).

According to the OECD (2017), productivity is an engine of economic growth and welfare. Labour productivity growth implies a high level of production per unit of labour factor (measured by hours worked or by the stock of employees).

The process of European integration has allowed greater flows of labour and capital, which has resulted in a significant growth of the Member Countries, in some cases as in the case of Spain the growth has reached $75 \%$ since 1980 (Derbyshire et al., 2010).
Therefore, the starting point for this study is to learn how the process of European integration has contributed to the economic growth of European countries. In this sense, we can formulate the following hypothesis:

H1. The gross domestic product per capita, GDPPC across the studied sample countries has grown positively in the analysed period (also known as the European integration process).

However, further progress towards integration into a single market must address regulatory and competition barriers that hinder the innovation process (OECD, 2019a). Thus, European companies have regularly experienced difficulties with incorporation of the latest technologies into their production processes, which impairs their efficiency (Gamberoni et al., 2016; Draghi, 2016). By the same token, networks in European industrial sectors continue to be highly fragmented at national levels, and the integration of capital markets continues to be over-regulated "hindering competition, investment and productivity growth" (OECD, 2019a, 3).

Moreover, labour mobility within the EU has been curtailed for a long time by regulatory problems, including the mutual recognition of qualifications, transferability of pension entitlements and social benefits, and the eligibility requirements for the Blue Card scheme (OECD, 2019a, 2015).

In recent decades, it has been observed that labour productivity growth in some European countries has been driven by an increase in the level of education of the workforce whereas in other countries (especially on the periphery) it has been driven by an increase in the number of workers, partly due to migration, although in the latter case its impact is more limited as it is mainly low-skilled labour (OECD, 2015).

The policies of each country affect their factor endowments, having a great impact on their productivity and on the quality and quantity of their workers (Ojeda-Gonzalez et al., 2018a; Melchor-Ferrer et al., 2017; European Commission, 2014). However, under Heckscher-Ohlin's international trade model, differences in countries' relative resource endowments determine their productive specialisation and competitiveness (Hijzen \& Wright, 2010). Therefore, productivity and subsequently also economic growth differ between European countries according to their factor endowment strategies (OECD, 2019a).

In general, the level of GDPPC has been decreasing since the global financial crisis, mainly due to a higher structural unemployment (Gordon, 2016). Workers tend to move to new locations in response to changes in economic factors such as income and unemployment levels (Chassamboulli \& Palivos, 2014), as they strive to improve their financial conditions and well-being compared to their initial situation, and therefore they look for better opportunities in other destinations (Di Giovanni et al., 2015). This process is well known and it has been analysed thoroughly since the development of neoclassical migration theory.

Thus, an increase in the labour factor in other countries also leads to an increase in local labour participation and, subsequently, in the level of wealth, both in origin and destination countries associated with the foreign labour force (Miranda-Martel et al., 2018; Ojeda-Gonzalez et al., 2018b; Garcia-Rodriguez et al.). In origin countries, the benefits of migration comprise reduced unemployment and social spending, incomes from remittances and foreign direct

\footnotetext{
${ }^{1}$ https://www.abbreviations.com/abbreviation/Gross+Domestic+P roduct+Per+Capita
} 
investment. And as for receiving countries, foreign workers contribute to higher participation rates, an increased number of young workers, new income through taxes and social contributions (Mihi-Ramirez et al., 2018; Grossman \& Stadelmann, 2012).

Consequently, as a next step of this study, an analysis is made of the relationship between labour efficiency and economic growth in European countries, taking into account the stock of local and foreign workers. Thus, we propose the hypotheses 2 and 3 :

$\mathrm{H} 2$. The labour productivity of local workers positively influences economic growth;

H3. The labour productivity of foreign workers positively influences economic growth;

It is worth noting that raising labour participation through additional labour (workers) can reduce structural unemployment (Chassamboulli \& Palivos, 2014), which might be a powerful strategy for sustaining future productivity (Miranda-Martel et al., 2018; Gamberoni et al., 2016).

However, the productivity is also likely to be higher the better the capacity and talent of the labour force (GarciaRodriguez et al., 2015), which also leads to higher GDPPC levels (Daugeliene, 2007).

The theory of cumulative causation portrays migration as a selective process in which highly skilled workers have a higher probability of success (Massey et al., 1993).

By the same token, the human capital theory argues that the level of achievement influences immigrants' working conditions and performance (Becker, 1983).

Piore (1979) coined the dual \& segmented labour market theory, which asserts that international migration is driven by the labour demands in developed countries, thereby proving that, in this case, emigration is not caused by push factors in origin countries (low wages and high unemployment), but rather by pull factors in destination countries (Massey et al., 1993). This is referred to as economic dualism: in modern capitalism the labour market is unequal and two systems coexist, the primary and the secondary one (Garcia-Rodriguez et al., 2015). In the former, production is capital-intensive and offers highly skilled jobs, stability, security, promotion prospects, equity, good wages and favourable employment termination conditions so as to retain workers. Such a system attracts local and foreign skilled labour. The second system, however, relates to labourintensive production and offers low-skilled and low-paid jobs, severe discipline and instability, unpleasant or dangerous working conditions with minimal social benefits, and difficulties in promotion and unfavourable employment contract termination conditions. The latter system is generally handled by unskilled immigrants and is characterised by a high rotation rate (Marshall, 2006).

The study conducted by Benassy \& Brezis (2013) showed how political intervention in the field of skilled migration influences each country's system in a predominant way, and these authors discuss three possible levels of interventionism: low level, which leads to a small balance between human capital, wages and production; high level intervention, with a good balance between the values of human capital, wages and GDP; and finally a scenario of many dynamic balances, in which what happened in the past is decisive. The study therefore concludes that the level of intervention determines the growth of human and intellectual capital in the economy.
Such a situation prevails in European countries, leading to profound structural changes that pose new challenges and opportunities. On the one hand, some developed countries attract a large number of highly qualified immigrants through policies aimed at encouraging and retaining talent, since this group of workers stimulates productivity, innovation and long-term economic growth (Bosetti et al., 2015). Moreover, low-income countries face an increased risk of brain drain and the associated economic and social consequences (Jaffe \& Trajtienberg, 2002). Also, there are several European countries where education is one of the priorities, as it is considered crucial to ensure a high current and future labour participation, which improves productivity, and also is a key factor in attracting international talent (Garcia-Rodriguez, 2015).

In this respect, a significant number of education strategies concentrate on improving the allocation of resources for disadvantaged and underprivileged students and schools, on equal access to education, training and employment and on promoting vocational training, regardless of its source (OECD, 2019a). These strategies are also beneficial because they address labour market segmentation and improve the labour market inclusion of women, migrants, minorities and older workers, making them a pull factor for international talent.

These strategies also entail the development of excellence in the academic institutions, which ensures a higher level of education for locals, but also a prestigious international reputation, attracting and attaining talented international workers (Garcia-Rodriguez, 2015), since the qualifications and skills obtained in prestigious academic institutions are becoming of growing importance (Fossland, 2013).

In brief, when studying labour productivity, it is also relevant to take into account the effect of the workforce quality, measured by the workers' educational level. This leads us to formulate the hypothesis 4 .

H4: The level of workers' education positively influences labour productivity, stimulating economic growth.

\section{Methodology and Results}

This paper analyses the convergence between European countries through economic growth driven by labour productivity and local and foreign employment rates. Our study is conducted on the basis of the data for 13 OECD (European) countries (Austria, Belgium, Denmark, Finland, France, Germany, Ireland, Italy, Netherlands, Portugal, Spain, Sweden, Sweden, United Kingdom and United States) covering the period 2000-2018 (2019b, 2018). The methodology used in our study is an analysis of spatial panel data, relying on the Spatial Durbin Model (SDM) (Elhorst et al., 2013; Kubis \& Schneider, 2012; Anselin, 2005; Le Gallo \& Ertur, 2003).

In our model, the dependent variable is the cumulative annual growth rate of GDPPC, and the explanatory variables are the GDPPC initial value and labour productivity (in both cases the variables are lagged by five years).

The best performance among the spatial weight matrices are the two closest neighbours. Our results show that it gives a much better fit than other matrices (its residual variance value is lower than in the case of other matrices), therefore, this spatial matrix is employed to perform the whole analysis.

The second step involves selecting the most appropriate model, so as to confirm that fixed spatial and 
temporal effects are insignificant. To this end, we estimate the following OLS model without fixed effects and with spatial and temporal effects:

Equation 1

$$
\begin{aligned}
&\left(\frac{1}{5}\right) \ln \left(\frac{Y_{t}}{Y_{t-5}}\right)= \alpha_{t}+\ln \left(Y_{t-5}\right) \beta_{1}+\ln \left(L P_{t-5}\right) \beta_{2} \\
&+\ln \left(E R_{t-5}\right) \beta_{3}+\mu+\xi_{t}+u_{t} \\
& u_{t}=\lambda W u_{t}+\varepsilon_{t}
\end{aligned}
$$

here, $\left(\frac{1}{5}\right) \ln \left(\frac{Y_{t}}{Y_{t-5}}\right)$ denotes the cumulative annual growth rate of the GDPPC, measured over five-year periods; $\ln \left(Y_{t-5}\right), \ln \left(L P_{t-5}\right)$, and $\ln \left(E R_{t-5}\right)$ are the vectors of exogenous explanatory variables five years ago (GDPPC, labour productivity (LP) and employment ratios (ER) by educational level, respectively); $\lambda, W u_{t}$ and $\varepsilon_{t}$ are vectors of the spatial autocorrelation coefficient, the interaction effects among the disturbance terms of the different units, and the disturbance terms, respectively, and $\mu, \xi_{t}$ and $u_{t}$ are, respectively, the vector of spatial fixed or random effects, the time-period specific effects, and the disturbance term of the different units.

This model allows us to perform the first step, which consists of the analysis of convergence between the European countries from the studied sample. And also, as a second step, we evaluate the economic growth conditioned by labour productivity and employment rates, which can be considered as a proxy variable for initial human capital.

Following the estimation of the different model versions, a likelihood ratio test (logarithm) is performed and the results indicate that both hypotheses should be rejected regardless of the educational level considered, with a pvalue $<0.01$. As a result, it is possible to extend the model with fixed spatial and temporal effects.

The OLS model shows significant spatial and temporal fixed effects, so the next step is to select the most appropriate functional form, so as to comply with the steps 3 and 4, and to analyse the impact of employment rates in terms of educational level and nationality. The literature on spatial econometrics provides alternative specifications (Elhorst et al., 2013), among which the SDM model is one of the most commonly used because of its versatility, which consists in the inclusion of two model terms in its specification depending on the spatial effect considered, i.e. one related to an independent variable and the error term. Thus, when a spatial component is included in both independent and dependent variables of the equation [1], the MDF model that is estimated is as follows:

Equation 2

$$
\begin{aligned}
\left(\frac{1}{5}\right) \ln \left(\frac{Y_{t}}{Y_{t-5}}\right) & =\alpha_{t}+\mu_{t}+W\left(\frac{1}{5}\right) \ln \left(\frac{Y_{t}}{Y_{t-5}}\right) \delta \\
+ & \ln \left(Y_{t-5}\right) \beta_{1}+\ln \left(L P_{t-5}\right) \beta_{2} \\
+ & \ln \left(E R_{t-5}\right) \beta_{3}+W \ln \left(Y_{t-5}\right) \theta_{1} \\
+ & W \ln \left(L P_{t-5}\right) \theta_{2}+W \ln \left(E R_{t-5}\right) \theta_{3}+\varepsilon_{t}
\end{aligned}
$$

where, $\delta$ is the spatial autoregressive coefficient; $\alpha_{t}$ and $\mu_{t}$ are, respectively, time period and spatial fixed or random effects; $X_{t}$ is a matrix of exogenous explanatory variables; $\beta$ denotes a vector with unknown parameters to be estimated; $\theta$ is vector of fixed but unknown parameters to be estimated; and $\varepsilon_{t}$ is a vector of disturbance terms.
Tables 1 and 2 show the results of the SDM model estimation for panel data applied to the analysis of GDPPC growth in terms of the initial GDPPC, productivity and employment ratios by workers' educational level for both those born in a country in question and those born abroad. The negative sign of the estimated coefficients for the initial GDPPC can be observed, which is consistent with other studies in the literature and, in fact, demonstrates a process of convergence among the European countries from the studied sample. Irrespective of the level of education, countries with lower initial levels of GDPPC tend to grow faster than other countries with higher initial incomes, and vice versa. In all cases, the estimated coefficients are significant at $1 \%$ level, and the higher is the level of education, the higher the value. Despite the best calibration of the SDM model, the coefficient estimated for the autoregressive parameter is not significant (both for those born in a country in question and abroad), which implies that the growth of any given country's neighbours does not influence the country's own growth. The economic growth is affected, however, by the initial GDPPC of the neighbours, particularly when we introduce the employment rate of foreign-born people as an independent variable. But how does European integration contribute to the growth of European countries? The positive sign of the estimated

\begin{tabular}{|c|c|c|c|c|}
\hline Determinants & Total & High $^{2}$ & Medium & Low \\
\hline \multicolumn{5}{|l|}{$W\left(\frac{1}{5}\right) \ln \left(\frac{Y_{t}}{Y_{t-5}}\right)$ GDPPC } \\
\hline neighbours' growth & 0.0739 & 0.0741 & 0.07 & 0.0749 \\
\hline $\ln \left(Y_{t-5}\right)$ Initial GDPPC & $\begin{array}{r}0.4011 * * \\
*\end{array}$ & $\begin{array}{r}0.3568 * \\
* *\end{array}$ & $\begin{array}{r}0.296 \\
* * *\end{array}$ & $\begin{array}{r}0.3103 \\
* * *\end{array}$ \\
\hline$W \ln \left(Y_{t-5}\right)$ Neighbours' initial & & $0.1095^{*}$ & 0.059 & 0.1405 \\
\hline GDPPC & 0.0308 & $*$ & 4 & $* * *$ \\
\hline $\begin{array}{l}\ln \left(L P_{t-5}\right) \text { Initial labour } \\
\text { productivity (LP) }\end{array}$ & $\begin{array}{r}0.2893 * \\
* *\end{array}$ & $\begin{array}{r}0.2199 * \\
* *\end{array}$ & $\begin{array}{l}0.160 \\
2 * * *\end{array}$ & $\begin{array}{r}0.1974 \\
* * *\end{array}$ \\
\hline$W \ln \left(L P_{t-5}\right)$ Neighbours' initial & \multicolumn{4}{|c|}{0.095} \\
\hline lab. productiv. & 0.084 & -0.0017 & * & 0.0017 \\
\hline $\ln \left(E R_{t-5}\right)$ Initial employment & $0.1527 *$ & $0.1248^{*}$ & 0.002 & \\
\hline ratio $(\mathrm{ER})$ & ** & ** & 5 & 0.0121 \\
\hline $\begin{array}{l}W \ln \left(E R_{t-5}\right) \text { Neighbours' initial } \\
\text { employ. ratio }\end{array}$ & $\begin{array}{r}0.1656^{*} \\
*\end{array}$ & 0.0781 & $\begin{array}{r}0.144 \\
9^{* * * *}\end{array}$ & 0.0252 \\
\hline Residual variance $\left(\sigma^{2}\right)$ & $\begin{array}{r}2.62 \mathrm{E}- \\
05\end{array}$ & $\begin{array}{r}2.75 \mathrm{E}- \\
05\end{array}$ & $\begin{array}{r}2.78 \mathrm{E} \\
-05\end{array}$ & $\begin{array}{r}2.95 \mathrm{E}- \\
05\end{array}$ \\
\hline $\mathrm{R}^{2}$ & \multicolumn{4}{|c|}{0.860} \\
\hline & & & 559.4 & 555.15 \\
\hline Log-likelihood & 563.610 & 559.967 & 07 & 8 \\
\hline Observations & 143 & 143 & 143 & 143 \\
\hline
\end{tabular}
coefficients for the initial GDPPC of neighbouring countries implies that rich countries tend to reinforce the growth of neighbouring countries, creating conglomerates with a similar level of development.

Table 1

Estimation Results by Place of Birth (Born in the Territory)

Note: Statistic significant: *at $10 \%$ level, **at $5 \%$ level, ***at $1 \%$ level.

The values of these coefficients are lower than those corresponding to the country's initial GDPPC (especially for workers born in the country in question), so that when a given country is surrounded by other countries with a similar level of development, the convergence effect tends to be reduced by about two thirds for those born abroad and somewhat to a lesser extent for those born in the country. 
On the other extreme, when a low-income country is surrounded by high-income countries, its growth is strongly reinforced and, therefore, also the convergence.

It means that the hypothesis 1 is partially accepted, and that a direct growth only occurs in the case of countries with different levels of wealth. These processes would be supported by (Kubis \& Schneider 2012): i) the processes of diffusion and delocalisation of economic activity related to saturation situations; ii) the indirect effects of the environment in high-income countries; and iii) the rising economies of scale in neighbouring countries.

However, since the beginning of the period under study (2000), rich European countries have experienced a strong cumulative growth. The explanation has to do with their own efforts to improve human capital through investments in education.

Table 2

Estimation Results by Place of Birth (Foreign Born)

\begin{tabular}{|c|c|c|c|c|}
\hline Determinants & Total & High & Medium & Low \\
\hline $\begin{array}{l}W\left(\frac{1}{5}\right) \ln \left(\frac{Y_{t}}{Y_{t-5}}\right) \\
\text { neighbours' growth }\end{array}$ & 0.074 & 0.0749 & 0.075 & 0.0746 \\
\hline $\ln \left(Y_{t-5}\right)$ Initial GDPPC & $-\overline{0.312 * * *}$ & $\begin{array}{l}- \\
0.2936^{*} \\
* *\end{array}$ & $\begin{array}{l}- \\
0.294 \\
3 * * *\end{array}$ & $\begin{array}{l}0.2773 \\
* * *\end{array}$ \\
\hline $\begin{array}{l}W \ln \left(Y_{t-5}\right) \text { Neighbours' initial } \\
\text { GDPPC }\end{array}$ & $\begin{array}{l}0.1814 * \\
* *\end{array}$ & $\begin{array}{l}0.1768 * \\
* *\end{array}$ & $\begin{array}{l}0.189 \\
4 * * *\end{array}$ & $\begin{array}{l}0.2193 \\
* * *\end{array}$ \\
\hline 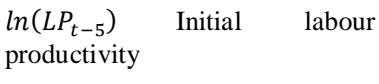 & $0.2085 *$ & $\begin{array}{l}0.1923 * \\
* *\end{array}$ & $\begin{array}{l}0.194 \\
6^{* * * *}\end{array}$ & $\begin{array}{l}0.1835 \\
* * *\end{array}$ \\
\hline $\begin{array}{l}W \ln \left(L P_{t-5}\right) \text { Neighbours' initial } \\
\text { lab. productiv. }\end{array}$ & -0.0294 & -0.0303 & $\begin{array}{l}0.044 \\
5\end{array}$ & 0.0756 \\
\hline $\begin{array}{l}\ln \left(E R_{t-5}\right) \text { Initial employment } \\
\text { ratio }\end{array}$ & 0.0168 & 0.0021 & 0.003 & $\overline{-}-0058$ \\
\hline $\begin{array}{l}W \ln \left(E R_{t-5}\right) \text { Neighbours' initial } \\
\text { employ. ratio }\end{array}$ & -0.0074 & -0.0017 & $\begin{array}{l}0.011 \\
1\end{array}$ & $\begin{array}{l}0.0183 \\
*\end{array}$ \\
\hline Residual variance $\left(\sigma^{2}\right)$ & $\begin{array}{l}2.96 \mathrm{E}- \\
05\end{array}$ & $\begin{array}{l}2.99 \mathrm{E}- \\
05\end{array}$ & $\begin{array}{l}2.98 \mathrm{E} \\
-05\end{array}$ & $\begin{array}{l}2.91 \mathrm{E}- \\
05\end{array}$ \\
\hline $\mathrm{R}^{2}$ & 0.8514 & 0.8494 & $\begin{array}{l}0.849 \\
6\end{array}$ & 0.8528 \\
\hline Log-likelihood & 554.861 & 554.091 & $\begin{array}{l}554.2 \\
22\end{array}$ & $\begin{array}{l}556.03 \\
9\end{array}$ \\
\hline Observations & 143 & 143 & 143 & 143 \\
\hline
\end{tabular}

Note: Statistic significant: * at $10 \%$ level, ** at $5 \%$ level, *** at $1 \%$ level.

With respect to labour productivity, its relevance is similar, but the sign of the estimated coefficients is positive, indicating a direct relationship between the initial value of labour productivity and GDPPC growth. The value of the estimated coefficients is very similar regardless of the level of education (appx. 0.19), but slightly higher when the employment rates for high levels of education are introduced as a stand-alone variable. This indicates that a $10 \%$ growth in a country's initial labour productivity leads to a $1.9 \%$ growth in the cumulative annual GDPPC rate. On the other hand, the initial labour productivity of neighbouring countries is not significant (with the exception of those born in the country with a moderate level of education) and, furthermore, the values are very low, which indicates that labour productivity of neighbouring countries plays a minor role in determining countries' economic growth.

With regards to employment rates by educational level, for local workers, we find that employment rates (for all) and a high level of education have a significant impact on GDPPC growth (see Table 1). Hence the hypothesis 2 is confirmed. Furthermore, the initial employment rate of neighbouring countries is only significant for those born in the country with a medium educational level, with the value (0.145) slightly higher than the one observed for the high educational level. This means that employment rates for an average level of education in neighbouring countries form a regional group that strengthens the growth of a given country. In all cases, the sign of estimated coefficients is positive and indicates a direct relationship between these factors and GDPPC growth (see Table 3). The direct effect is significant only for the high educational level, whereas the indirect effect is for the medium educational level. In the first case, this means that an increase in the employment rate for a specific country has a positive and statistically significant impact on the GDPPC growth rate. In other words, a value of 0.1555 for this parameter indicates that an average $10 \%$ increase in a country's ratio leads to a reinforcement of its cumulative growth rate by $1.54 \%$. As shown in Table 3, this impact is slightly higher (0.030) than the estimated parameter value, thus we can affirm that the feedback effects between the growth of a region and that of its neighbours are relevant. This happens because direct effects arise as a result of impacts that are passed through from one region to another and return to the same region.

Table 3

Estimation of Direct, Indirect and Total Effects (Born in the Territory)

\begin{tabular}{|c|c|c|c|}
\hline Variable & Direct effects & $\begin{array}{c}\text { Indirect } \\
\text { effects }\end{array}$ & Total effects \\
\hline \multicolumn{4}{|l|}{$\begin{array}{ll}\text { All } & \text { educational } \\
\text { levels }\end{array}$} \\
\hline GDPPC & $\begin{array}{r}-0.4003 * * * \\
(0.000)\end{array}$ & $\begin{array}{l}0.0002 \\
(0.998)\end{array}$ & $\begin{array}{r}-0.4001 * * * \\
(0.000)\end{array}$ \\
\hline Labour productivity & $\begin{array}{r}0.2904 * * * * \\
(0.000)\end{array}$ & $\begin{array}{l}0.1161 \\
(0.165)\end{array}$ & $\begin{array}{r}0.4065^{* * * *} \\
(0.000)\end{array}$ \\
\hline Employment ratio & $\begin{array}{r}0.1542 * * * * \\
(0.005) \\
\end{array}$ & $\begin{array}{r}0.1916^{*} \\
(0.056)\end{array}$ & $\begin{array}{r}0.3458 * * * \\
(0.005) \\
\end{array}$ \\
\hline \multicolumn{4}{|l|}{$\begin{array}{l}\text { High educational } \\
\text { level }\end{array}$} \\
\hline GDPPC & $\begin{array}{r}-0.356 * * * \\
(0.000)\end{array}$ & $\begin{array}{r}0.0888^{*} \\
(0.081)\end{array}$ & $\begin{array}{r}-0.2672 * * * * \\
(0.001)\end{array}$ \\
\hline Labour productivity & $\begin{array}{r}0.2189 * * * * \\
(0.000)\end{array}$ & $\begin{array}{l}0.0138 \\
(0.778)\end{array}$ & $\begin{array}{r}0.2327 * * * \\
(0.001)\end{array}$ \\
\hline Employment ratio & $\begin{array}{r}0.1255^{* *} \\
(0.017) \\
\end{array}$ & $\begin{array}{l}0.0938 \\
(0.227) \\
\end{array}$ & $\begin{array}{r}0.2193 * * \\
(0.025) \\
\end{array}$ \\
\hline \multicolumn{4}{|l|}{$\begin{array}{l}\text { Medium } \\
\text { educational level }\end{array}$} \\
\hline GDPPC & $\begin{array}{r}-0.2945^{* * * *} \\
(0.000)\end{array}$ & $\begin{array}{l}0.0451 \\
(0.413)\end{array}$ & $\begin{array}{r}-0.2494 * * * \\
(0.005)\end{array}$ \\
\hline Labour productivity & $\begin{array}{r}0.1619 * * * \\
(0.001)\end{array}$ & $\begin{array}{r}0.1081^{*} \\
(0.08)\end{array}$ & $\begin{array}{r}0.27 * * * \\
(0.001)\end{array}$ \\
\hline Employment ratio & $0.004(0.910)$ & $\begin{array}{r}0.1497 * * \\
(0.014) \\
\end{array}$ & $\begin{array}{r}0.1537 * * \\
(0.036) \\
\end{array}$ \\
\hline \multicolumn{4}{|l|}{$\begin{array}{l}\text { Low educational } \\
\text { level }\end{array}$} \\
\hline GDPPC & $\begin{array}{r}-0.3084 * * * * \\
(0.000)\end{array}$ & $\begin{array}{r}0.1255^{* *} \\
(0.021)\end{array}$ & $\begin{array}{r}-0.183 * * \\
(0.015)\end{array}$ \\
\hline Labour productivity & $\begin{array}{r}0.1962 * * * * \\
(0.000)\end{array}$ & $\begin{array}{l}0.0159 \\
(0.782)\end{array}$ & $\begin{array}{r}0.2121 * * * * \\
(0.007)\end{array}$ \\
\hline Employment ratio & $\begin{array}{l}0.0128 \\
(0.464) \\
\end{array}$ & $\begin{array}{r}0.028 \\
(0.331) \\
\end{array}$ & $\begin{array}{r}0.0407 \\
(0.229) \\
\end{array}$ \\
\hline
\end{tabular}

Note: p-value shown in brackets. Statistic significant: * at $10 \%$ level, ** at $5 \%$ level, *** at $1 \%$ level.

On the other hand, indirect effects reflect the impact of changes in neighbouring regions' independent variables on a region's dependent variable. In this study, only the employment rate of those born in the country with a medium level of education is significant at $5 \%$ level. This illustrates that there is a positive impact of the aforementioned ratio in neighbouring countries on GDPPC growth of the country in question. 
As a consequence of the aforementioned, the overall effect of the employment rate for high and medium educational level is significant at $5 \%$ level, and more specifically for the former, since its value $(0.2193)$ is much higher compared to the medium educational level (0.1537). At all levels of education, the positive effect of employment rates, coupled with the positive labour productivity effect, is much greater than the negative effect of GDPPC (especially in the case of high and medium educational levels), indicating a positive effect that productivity and employment rates exert on economic growth. Hence the importance of promoting education policies centred on improving human capital. In view of the foregoing, it can be concluded that for European countries there is a positive relationship between the initial level of the employment rate of those born in a particular country and the growth of GDPPC, both for the country (region) itself and for its neighbours, which demonstrates the existence of spatial spillovers.

On the other hand, taking into account those born abroad, their ratios do not have a significant influence on GDPPC growth. We can therefore conclude that such backlash does not seem to have a significant impact on the economic growth of European countries (see Table 4).

Table 4

Estimation of Direct, Indirect and Total Effects (Foreign Born)

\begin{tabular}{|c|c|c|c|}
\hline Variable & Direct effects & Indirect effects & Total effects \\
\hline \multicolumn{4}{|l|}{$\begin{array}{l}\text { All educational } \\
\text { levels }\end{array}$} \\
\hline GDPPC & $\begin{array}{r}-0.306 * * * \\
(0.000)\end{array}$ & $\begin{array}{r}0.1726 * * * \\
(0.002)\end{array}$ & $\begin{array}{r}-0.1334 * * \\
(0.043)\end{array}$ \\
\hline $\begin{array}{l}\text { Labour } \\
\text { productivity }\end{array}$ & $\begin{array}{r}0.2054 * * * \\
(0.000)\end{array}$ & $\begin{array}{r}-0.0174 \\
(0.733)\end{array}$ & $\begin{array}{r}0.188 * * \\
(0.015)\end{array}$ \\
\hline Employment ratio & $\begin{array}{l}0.0157 \\
(0.323)\end{array}$ & $\begin{array}{r}-0.0077 \\
(0.735) \\
\end{array}$ & $\begin{array}{l}0.0079 \\
(0.789)\end{array}$ \\
\hline \multicolumn{4}{|l|}{$\begin{array}{l}\text { High educational } \\
\text { level }\end{array}$} \\
\hline GDPPC & $\begin{array}{r}-0.2913 * * * \\
(0.000)\end{array}$ & $\begin{array}{r}0.1655^{* * * *} \\
(0.001)\end{array}$ & $\begin{array}{r}-0.1258 * * \\
(0.026)\end{array}$ \\
\hline $\begin{array}{l}\text { Labour } \\
\text { productivity }\end{array}$ & $\begin{array}{r}0.1922 * * * * \\
(0.000)\end{array}$ & $\begin{array}{r}-0.0192 \\
(0.658)\end{array}$ & $\begin{array}{r}0.173 * * * \\
(0.008)\end{array}$ \\
\hline Employment ratio & $\begin{array}{l}0.0023 \\
(0.840) \\
\end{array}$ & $\begin{array}{r}-0.0013 \\
(0.925)\end{array}$ & $\begin{array}{r}0.001 \\
(0.957)\end{array}$ \\
\hline \multicolumn{4}{|l|}{$\begin{array}{l}\text { Medium } \\
\text { educational level }\end{array}$} \\
\hline GDPPC & $\begin{array}{r}-0.2906 * * * * \\
(0.000)\end{array}$ & $\begin{array}{r}0.18 * * * \\
(0.006)\end{array}$ & $\begin{array}{r}-0.1106 \\
(0.157)\end{array}$ \\
\hline $\begin{array}{l}\text { Labour } \\
\text { productivity }\end{array}$ & $\begin{array}{r}0.1931 * * * \\
(0.000)\end{array}$ & $\begin{array}{r}-0.0348 \\
(0.568)\end{array}$ & $\begin{array}{r}0.1584^{*} \\
(0.066)\end{array}$ \\
\hline Employment ratio & $\begin{array}{l}0.0022 \\
(0.904) \\
\end{array}$ & $\begin{array}{r}-0.0119 \\
(0.669)\end{array}$ & $\begin{array}{r}-0.0098 \\
(0.793)\end{array}$ \\
\hline \multicolumn{4}{|l|}{$\begin{array}{l}\text { Low educational } \\
\text { level }\end{array}$} \\
\hline GDPPC & $\begin{array}{r}-0.2735 * * * \\
(0.000)\end{array}$ & $\begin{array}{r}0.2134 * * * \\
(0.001)\end{array}$ & $\begin{array}{r}-0.0601 \\
(0.341)\end{array}$ \\
\hline $\begin{array}{l}\text { Labour } \\
\text { productivity }\end{array}$ & $\begin{array}{r}0.1839 * * * \\
(0.000)\end{array}$ & $\begin{array}{r}-0.0653 \\
(0.223)\end{array}$ & $\begin{array}{r}0.1186^{*} \\
(0.090)\end{array}$ \\
\hline Employment ratio & $\begin{array}{r}-0.0061 \\
(0.452)\end{array}$ & $\begin{array}{r}-0.0199 \\
(0.135)\end{array}$ & $\begin{array}{r}-0.026 \\
(0.118)\end{array}$ \\
\hline
\end{tabular}

Note: p-value shown in brackets. Statistic significant: * at $10 \%$ level, ** at $5 \%$ level, *** at $1 \%$ level
However, the correct interpretation of the estimated coefficients requires that direct, indirect and overall effects associated with changes in the explanatory variables are taken into account. Therefore, focusing on the employment rates of foreign-born persons (cf. Table 4), it can be argued that none of the indicators is significant and that their values are very low, meaning that they do not explain the GDPPC growth. Therefore, there is no evidence supporting the hypothesis 3 in that labour productivity of foreigners positively influences economic growth.

This can be explained by a number of factors: i) the lower value of the proportions for a high level of education and the higher value for a low level of education; ii) the fact that a large proportion of the immigrant population is associated with lower levels of education and is employed in low-skilled jobs ( as evidenced by the higher employment rate among native-born individuals); and iii) the lower relative status of foreign-born people, despite the fact that they have been living in Europe for years and have improved their level of qualification.

With respect to the hypothesis 4 , the results evidenced in Table 4 show a positive influence of highly and intermediately skilled workers' labour productivity on economic growth, thereby affirming that active policies promoting education also serve to attract foreign workers, which has a positive impact on growth. The positive impact on rising well-being reinforces our conviction that migration of skilled workers to those countries will be sustained, which significantly strengthens the labour force. Furthermore, the literature indicates that skilled labour migration creates networks conducive to its concentration (Garcia-Rodriguez, 2015). It is therefore logical to assume that negative effects of the brain drain can intensify, thus enriching each country's factors endowment and ultimately its level of development.

\section{Conclusions}

This paper examines the differences in the level of growth between European countries in terms of labour productivity. Given the existence of relevant barriers in the diffusion and implementation of innovation in European companies and the fact that accumulation of capital in recent years has not translated into similar increases in productivity, we concentrate our attention on the efficiency of labour productivity to explain such differences in growth.

It is noted that convergence between European countries is effective, but when wealth levels are similar, the level of development depends more on the strategy adopted by each country. According to our results and in line with the Heckscher-Ohlin approach and with the economic dualism, countries that invest in the long-term improvement of their human capital manage over time to improve their factor endowment, which also allows for a greater accumulation of local talent, and attracts foreign skilled workers. All in all, this implies higher productivity and competitiveness and therefore higher levels of growth.

\section{References}

Anselin, L. (2005). Exploring Spatial Data with GeoDa: A Workbook 1EB/OL. Illinois: Center for Spatially Integrated Social Science.

Ark, B. van, O'Mahony, M., \& Timmer, M. (2008). The productivity gap between Europe and the U.S.: Trends and Causes. Journal of Economic Perspectives, 22(1), 25-44. https://doi.org/10.1257/jep.22.1.25 
Becker, G. S. (1983). A Theory of Competition among Pressure Groups for Political Influence. Quarterly Journal of Economics, 98(3), 371-400. https://doi.org/10.2307/1886017

Benassy, J. P., \& Brezis, E. S. (2013). Brain drain and development traps. Journal of Development Economics, 102, 15-22. https://doi.org/10.1016/j.jdeveco.2012.11.002

Bosetti, V., Cattaneo, C., \& Verdolini, E. (2015). Migration of skilled workers and innovation: a European perspective. Journal of International Economics, 96, 311-322. https://doi.org/10.1016/j.jinteco.2015.04.002

Chassamboulli, A., \& Palivos, T. (2014). A Search-Equilibrium Approach to the Effects of Immigration on Labor Market Outcomes. International Economic Review, 55(1), 111-129. https://doi.org/10.1111/iere.12043

Ciccone, A., \& Hall, R. E. (1996). Productivity and the Density of Economic Activity. American Economic Review, 86(1), 54-70.

Conesa, J. C., \& Kehoe, T. J. (2018). An introduction to the macroeconomics of aging. The Journal of the Economics of Ageing, 11, 1-5. https://doi.org/10.1016/j.jeoa.2018.03.002

Di Giovanni, J., Levchenko, A. A., \& Ortega, F. (2015). A global view of cross-border migration. Journal of the European Economic Association, 13(1), 168-202. https://doi.org/10.1111/jeea.12110

Daugeliene, R. (2007). The Peculiarities of Knowledge Workers Migration in Europe and the World. Inzinerine EkonomikaEngineering Economics, 53(3), 57-64.

Draghi, M. (2016). The productivity challenge for Europe. Europe Central Bank. Available from internet: https://www.ecb.europa.eu/press/key/date/2016/html/sp161130_1.en.html

Elhorst, Jp., Zandberg, E., \& De Haan, J. (2013). The impact of interaction effects among neighbouring countries on financial liberalization and reform: a dynamic spatial panel data approach. Spatial Economic Analysis 8(3), $293-313$. https://doi.org/10.1080/17421772.2012.760136

European Commission (2014). Reindustrialising Europe. Member States' Competitiveness Report 2014. Luxembourg.

Fossland, T. (2013). Negotiating future careers. A relational perspective on skilled migrants' labour market participation. Journal of Management Development, 32(2), 193-203. https://doi.org/10.1108/02621711311305692

Garcia-Rodriguez, Y., Mihi-Ramirez, A., \& Navarro-Pabsdorf, M. (2015). Highly-Skilled Migration, Migrant Networks and the Prestige of Academic Institutions. Inzinerine Ekonomika-Engineering Economics, 26(5), 500-506. https://doi.org/10.5755/j01.ee.26.5.12463

Gamberoni, E., Giordano, C., \& Lopez-Garcia, P. (2016). Capital and labor (mis)allocation in the euro area: some stylized facts and determinants. ECB Working Paper No 1981. https://doi.org/10.2139/ssrn.2910362

Gordon, R. (2016). The Rise and Fall of American Growth: The US Standard of Living since the Civil War, Princeton University Press. https://doi.org/10.1515/9781400873302

Greenstone, M., Hornbeck, R., \& Moretti, E. (2010). Identifying Agglomeration Spillovers: Evidence from Winners and losers of Large Plant Openings. Journal of Political Economy, 118(3), 536-98. https://doi.org/10.1086/653714

Grossman, V., \& Stadelmann, D. (2012). Does High-skilled Migration Affect Publicly Financed Investments? Review of International Economics, 20(5), 944-959. https://doi.org/10.1111/roie.12005

Hijzen, A., \& Wright, P. W. (2010). Migration, trade, and wages. Journal of population economics, 23(4), 1189-1211. https://doi.org/10.1007/s00148-009-0241-z

Jaffe, A. B., \& Trajtienberg, M. (2002). Patents, Citations \& Innovations: A Window on the Knowledge Economy. Cambridge, MA: MIT Press. https://doi.org/10.7551/mitpress/5263.001.0001

Klugea, A., Joshua R., Goldsteinb, T., \& Vogtc, C. (2019). Transfers in an aging European Union Fanny. The Journal of the Economics of Ageing, 13, 45-54. https://doi.org/10.1016/j.jeoa.2018.07.004

Kubis, A., \& Schneider, L. (2012). Human capital mobility and convergence: a spatial dynamic panel model of the German regions. Technical report, Institut für Arbeitsmarkt-und Berufsforschung (IAB), Discussion Paper, Nuremberg, Germany.

Le Gallo, \& Ertur, C. (2003). Exploratory spatial data analysis of the distribution of regional per capita GDP in Europe, 1980-1995. Papers in Regional Science 82(2), 175-201. https://doi.org/10.1007/s101100300145

Lewis, E. (2005). Immigration, Skill Mix and the Choice of Technique. Federal Reserve Bank of Philadelphia, Working Paper 8. https://doi.org/10.21799/frbp.wp.2005.08

Marshall, B. (2006). Introduction at the Politics of Migration: A Survey. London: Routledge, 3-11. .https://doi.org/10. 4324/9781315728285-1

Massey, D., Arango, J., Hugo, G., Kouaouci, A., Pellegrino, A., \& Taylor, J. (1993). Theories of International Migration: A Review and Appraisal. Population and Development Review, 19(3), 431-466. https://doi.org/10.2307/2938462

Melchor-Ferrer, E., Mihi-Ramirez, A., \&Arteaga-Ortiz, J. (2017). Migraciones y convergencia especial de la productividad en Europa. Informacion Comercial Espanola, ICE, 899, 83-96, Ministerio de Economia y Competitividad. 
Melchor-Ferrer, E., Mihi-Ramirez, A., \& Agoh, E. (2018). Regional convergence in Europe: evidence from the perspective of capital accumulation in services. Research in Economics and Business: Central and Eastern Europe, 9(2), 5-19

Mihi-Ramirez, A., Arteaga-Ortiz, J., \& Ojeda-Gonzalez, S. (2019). The international movements of capital and labor: a study of foreign direct investment and migrations flows. Entrepreneurial Business and Economics Review, 7(3),143-160. https://doi.org/10.15678/EBER.2019.070308

Mihi-Ramirez, A., Ojeda-Gonzalez, S., Miranda-Martel, M., \& Agoh, E. (2018). The contribution of migration to economics growth. Evidence from Spain. Open Economics, 1, 124-130. https://doi.org/10.1515/openec-2018-0006

Miranda-Martel, M. J., Mihi-Ramirez, A., \& Arteaga-Ortiz, J. (2017). How the Level of Economic Growth and the Constituent Elements of Innovation Attract International Talent? Inzinerine Ekonomika-Engineering Economics, 28(2), 187-197. https://doi.org/10.5755/j01.ee.28.2.17518

Miranda-Martel, M. J., Mihi-Ramirez, A., \& Ojeda-Gonzalez, S. (2018). The role of immigrant workers in productivity and its main components in OECD countries, presented at 27th International Scientific Conference on Economic and Social Development, Rome (Italy) 2017: University North and Faculty of Management University of Warsaw.

OECD (2015). The Future of Productivity, OECD: Paris, France.

OECD (2016). OECD Compendium of Productivity Indicators 2016. Paris: OECD Publishing. https://doi.org/10. 1787/pdtvy-2016-en

OECD (2018). Employment rates by place of birth and educational. Database available from internet: attainmenthttps://stats.oecd.org/Index.aspx?DataSetCode=MIG_NUP_RATES_GENDER

OECD (2019a). Economic Policy Reforms 2019: Going for Growth, Paris: OECD Publishing.

OECD (2019b). Employment by education level. Database available from internet: https://data.oecd.org/emp/employmentby-education-level.htm

Ojeda-Gonzalez, S., Miranda-Martel, M. J., Agoh, E., \& Mihi-Ramirez, A. (2018a). The importance of immigration in labor productivity in Spain, presented at 10 International Scientific Conference Business and Management, Vilnius (Lithuania) 2018. Vilnius Gediminas Technical University.

Ojeda-Gonzalez, S., Mihi-Ramirez, A., Arteaga-Ortiz, J., \& Cuenca-Garcia, E. (2018b). Spain trade in view of some migratory and economic considerations. Inzinerine Ekonomika-Engineering Economics, 29(1), 53-61. https://doi.org/10.5755/j01.ee.29.1.19387

Peri, G. (2016). Immigrants, productivity, and labor markets. The Journal of Economic Perspectives, 30(4), 3-29. https://doi.org/10.1257/jep.30.4.3

Piore, M. J. (1979). Birds of passage: Migrant labor in industrial societies, New York: Cambridge University Press. https://doi.org/10.1017/CBO9780511572210

Requeijo, J. (2009). Odyssey 2050: XXI Century Global Economy. Madrid, Alianza editorial.

The article has been reviewed.

Received in October 2019; accepted in December 2019. 